\title{
The effect of strategic supplementation with trans-10,cis-12 conjugated linoleic acid on the milk production, estrous cycle characteristics, and reproductive performance of lactating dairy cattle
}

\author{
I. A. Hutchinson, ${ }^{\star} \S$ A. A. Hennessy,† R. J. Dewhurst,‡ A. C. O. Evans,§ P. Lonergan,§ and S. T. Butler ${ }^{\star 1}$ \\ ${ }^{*}$ Teagasc, Animal \& Grassland Research and Innovation Centre, Moorepark, Fermoy, Co. Cork, Ireland \\ †Teagasc Food Research Centre, Moorepark, Fermoy, Co. Cork, Ireland \\ ¥Teagasc, Animal \& Grassland Research and Innovation Centre, Grange, Dunsany, Co. Meath, Ireland \\ $\S$ School of Agriculture and Food Science, University College Dublin, Belfield, Dublin 4, Ireland
}

\begin{abstract}
The objective was to determine the effects of a protected (lipid-encapsulated) conjugated linoleic acid (LE-CLA) supplement on milk production, estrous cycle characteristics, and reproductive performance in lactating dairy cows on a pasture-based diet. Spring calving dairy cows $(\mathrm{n}=409)$ on a single pasture-based commercial dairy farm were used in a completely randomized block design. Cows were assigned to 1 of 2 dietary supplements [LE-CLA $(\mathrm{n}=203)$ or no supplement (control, $\mathrm{n}=206$ )]. The LE-CLA cows received $51 \mathrm{~g} / \mathrm{d}$ of a lipid supplement containing $5 \mathrm{~g}$ of both trans-10,cis-12 and cis-9,trans-11 CLA from 0 to $60 \mathrm{~d}$ in milk. Milk samples were collected 3 times weekly, and each sample was analyzed for progesterone to determine the interval to first ovulation and estrous cycle characteristics. Milk yield and concentrations of fat, protein, and lactose were measured every 2 wk. Cows were inseminated following visual observation of estrus. The breeding season commenced on April 8, 2009 and continued for $16 \mathrm{wk}$. Transrectal ultrasonography was carried out at 30 to $36 \mathrm{~d}$ and 60 to $66 \mathrm{~d}$ post-AI to diagnose pregnancy. The LE-CLA treatment resulted in a decrease in milk fat concentration $(36.9 \pm 0.06 \mathrm{~g} / \mathrm{kg}$ vs. $30.7 \pm 0.06 \mathrm{~g} / \mathrm{kg}$ for control and LE-CLA, respectively) and yield $(0.91 \pm 0.02 \mathrm{~kg} / \mathrm{d}$ vs. $0.84 \pm 0.02 \mathrm{~kg} / \mathrm{d}$ for control and LE-CLA, respectively); however, milk yield was increased by LE-CLA supplementation (24.7 $\pm 0.7 \mathrm{~kg} / \mathrm{d}$ vs. $27.2 \pm 0.7 \mathrm{~kg} / \mathrm{d}$ for control and LECLA, respectively), resulting in no overall difference in milk energy output. No effect of LE-CLA was observed on any estrous cycle characteristics or measures of reproductive performance. These results support that in pasture-based systems of dairy production, where energy intake limits milk production, energy spared by
\end{abstract}

Received June 17, 2011.

Accepted January 13, 2012.

${ }^{1}$ Corresponding author: stephen.butler@teagasc.ie
CLA-induced milk fat depression is partitioned toward increasing milk yield rather than toward body reserves. Key words: conjugated linoleic acid, reproduction, milk fat, energy balance

\section{INTRODUCTION}

The early postpartum period in dairy cattle is associated with negative energy balance (NEB) and mobilization of body reserves, as the energy requirements for maintenance and milk production exceed energy ingested (Bauman and Currie, 1980). Both the duration and severity of this period of NEB have detrimental effects on follicle development, postpartum resumption of ovarian cyclicity, and subsequent oocyte and embryo quality, resulting in decreased pregnancy rates (Beam and Butler, 1999; Diskin et al., 2003; Leroy et al., 2008).

Attempts to alleviate NEB have largely focused on increasing the energy density of the diet. Feeding supplemental fat generally results in an increase in nutrients partitioned toward milk production (Santos et al., 2008), or else DMI is suppressed so that total energy intake is unaffected (Staples et al., 1998).

Improved reproductive performance was reported in some studies where lactating dairy cows were supplemented with PUFA. Although results have been inconsistent (Santos et al., 2008), it would appear that reproductive performance may be improved by the specific effects of individual FA, independent of energy status.

Conjugated linoleic acids (CLA) are geometric and positional isomers of linoleic acid, and are normally found in the rumen as intermediates in the biohydrogenation of linoleic to stearic acid. Trans-10, cis-12 CLA was identified as a potent inhibitor of milk fat synthesis (Baumgard et al., 2002), with a dose-dependent response of up to $50 \%$ reduction in milk fat synthesis (de Veth et al., 2004). Milk volume and milk protein concentration were not decreased by CLA supplementation, and milk fat concentration quickly returned to control levels on termination of CLA supplementation (Castañeda- 
Gutiérrez et al., 2007). Fat is the most energetically expensive component of milk, representing up to $35 \%$ of net energy intake in early lactation (Bauman and Currie, 1980). Feeding supplemental CLA may be a means of decreasing milk energy output and ameliorating NEB postpartum, with subsequent improvements in reproductive performance. Some studies reported no improvement in energy status, with energy spared being partitioned toward increased milk volume (BernalSantos et al., 2003), whereas other reports indicated decreases in milk energy output with CLA supplementation (Odens et al., 2007; Hutchinson et al., 2011). A recent meta-analysis of 5 controlled studies in which early-lactation dairy cows had been supplemented with CLA indicated that CLA supplementation shortened the interval to first ovulation and time to conception, and increased the probability of cows becoming pregnant (de Veth et al., 2009). The studies included in the meta-analysis used a small number of cows (total $\mathrm{n}=$ 212), and determining the effects of CLA on reproductive performance was not a primary objective in any of the 5 studies included in the meta-analysis. To date, there has been no herd-scale evaluation of the effect of protected (lipid-encapsulated) CLA (LE-CLA) on reproductive performance in lactating dairy cattle. The aim of the present study was to examine the effects of CLA supplementation on milk production and reproductive performance of lactating dairy cows in a pasture-based system of production under commercial conditions.

\section{MATERIALS AND METHODS}

\section{Animals, Treatments, and Sampling}

A total of 409 primiparous and multiparous springcalving Holstein-Friesian dairy cows on a single pasturebased commercial dairy farm in County Cork, Ireland $\left(52^{\circ} 05^{\prime} \mathrm{N} ; 8^{\circ} 16^{\prime} \mathrm{W}\right)$ were blocked on the basis of parity $(1,2$, and $>2)$ and calving date, and randomly assigned to receive 1 of 2 dietary treatments from parturition until 60 DIM: LE-CLA ( $\mathrm{n}=203$; Lutrell; BASF, Ludwigshafen, Germany) or no supplement (control, $\mathrm{n}=$ 206). The mean calving date was February 23, 2009 $(\mathrm{SD}=29 \mathrm{~d}$; range = January 4, 2009, to April 26, 2009). Prior to parturition, all cows were managed in the same manner, housed indoors, and fed a grass silage diet. Following parturition, the cows were managed as a single herd and milked twice daily at 0700 and 1600 $\mathrm{h}$ in a 60-unit rotary parlor with automatic cow identification, automatic concentrate feeding, and electronic milk meters (Dairymaster, Causeway, Kerry, Ireland). Every cow was offered the same basal diet of grazed grass and a concentrate ration fed in the parlor at milk- ing times. In late winter and early spring, when grass growth was limited by weather conditions, they were fed a forage diet based on a 50:50 mix of grass silage and corn silage supplemented with $2 \mathrm{~kg} /$ cow per day of soybean meal. The parlor concentrate supplement was fed at a rate of $6 \mathrm{~kg} / \mathrm{cow}$ per day in late winter, and was gradually decreased to $1 \mathrm{~kg} / \mathrm{cow}$ per day as grass growth increased. The chemical composition of the feeds offered (partial mixed ration, silage mix, grazed grass, and parlor concentrate supplement) is in Table 1. The LE-CLA cows were individually fed an additional 51 $\mathrm{g} / \mathrm{d}$ of lipid supplement from parturition until 60 DIM. The LE-CLA supplement contained a 50:50 mix of cis9,trans-11 CLA and trans-10,cis-12 CLA, resulting in a daily intake of $5 \mathrm{~g} / \mathrm{d}$ of each isomer. The LE-CLA supplement was automatically dispensed to individual cows in granular form using a PowerDos feeding system (Hanskamp AgroTech BV, Zelhem, the Netherlands) simultaneous with the concentrate allocation. The PowerDos system delivered the supplement from a hopper via a pneumatic stainless steel dosage mechanism. As this mechanism was able to deliver a maximum of 17 $\mathrm{g}$ of LE-CLA in a single dose, the feeding system was programmed to feed a double dose (34 g) at the morning milking and a single dose (17 g) at the evening milking. The feeding system was tested several times before the initiation of the study and at 2-wk intervals to ensure that the correct amount of LE-CLA was being provided to the cows. Milk yield was recorded daily at morning and evening milkings using electronic milk meters (Dairymaster). Milk composition (fat, protein, and lactose), was determined on a 2-wk basis from successive morning and evening milk samples by automated infrared absorption analysis using a Milkoscan 605 (Foss Electric A/S, Hillerød, Denmark).

The following equation was used to determine the milk energy output (O'Mara, 1997), using unité fourragère lait (UFL) as the unit of net energy, which is equivalent to $1 \mathrm{~kg}$ of standard air-dried barley:

$$
\begin{gathered}
\text { energy requirement for milk }(\mathrm{UFL} / \mathrm{kg} \text { of milk) }= \\
0.054 \mathrm{FC}+0.031 \mathrm{PC}+0.028 \mathrm{LC}-0.015,
\end{gathered}
$$

where $\mathrm{FC}=$ fat concentration $(\%), \mathrm{PC}=$ protein concentration (\%), and LC = lactose concentration (\%).

A total of 20 cows (9 control and 11 CLA) were removed from the experiment due to illnesses and metabolic problems unrelated to dietary treatment.

\section{Milk Progesterone Sampling and Analysis}

Milk samples from all cows enrolled in the study were collected at the morning milking 3 times weekly (Mon- 
Table 1. Chemical composition of the feeds offered to dairy cows on pasture

\begin{tabular}{lccc}
\hline $\begin{array}{l}\text { Nutrient composition } \\
\text { (g/kg of DM) }\end{array}$ & Grass & PMR $^{1}$ & Concentrate \\
\hline OM digestibility & 818.3 & 706.0 & - \\
CP & 256.4 & 120.1 & 249.2 \\
NDF & 487.6 & 480.0 & - \\
ADF & 253.8 & 274.7 & - \\
Crude fiber & - & - & 109.2 \\
Oil & - & - & 38.4 \\
Ash & 90.6 & 64.8 & 80.7 \\
\hline
\end{tabular}

${ }^{1}$ Partial mixed ration.

day, Wednesday, and Friday); a preservative was added to each sample (Lactab Mark III, Thomson and Capper Ltd., Cheshire, UK) and the samples were stored at $4^{\circ} \mathrm{C}$ until analysis. Milk progesterone (P4) concentrations were measured in all samples using a competitive ELISA test (Ridgeway Science, Gloucester, UK), based on published methods (Sauer et al., 1986). The interand intra-assay coefficients of variation were 14.5 and $9.1 \%$, respectively, and the sensitivity of the assay was $0.5 \mathrm{ng} / \mathrm{mL}$ (Sauer et al., 1986).

\section{Interval to First Ovulation}

A period of luteal activity was defined as the occurrence of 2 or more consecutive milk $\mathrm{P} 4$ concentrations $\geq 3 \mathrm{ng} / \mathrm{mL}$ (Darwash et al., 1997). The interval to first ovulation (IOV1) was defined as the first occurrence of luteal activity postpartum, or the first day on which milk $\mathrm{P} 4$ concentrations $\geq 3 \mathrm{ng} / \mathrm{mL}$ were observed, and meeting the above criteria.

\section{Abnormal Estrous Activity}

Abnormal estrous activity was identified based on previously published criteria (Royal et al., 2000). Prolonged anovulation postpartum, delayed ovulation type I (DOV I), was defined as milk P4 concentrations $<3$ $\mathrm{ng} / \mathrm{mL}$ for $\geq 45$ DIM. Prolonged interluteal interval, delayed ovulation type II (DOV II), was defined as milk $\mathrm{P} 4$ concentrations $<3 \mathrm{ng} / \mathrm{mL}$ for $\geq 12 \mathrm{~d}$ after the first occurrence of luteal activity postpartum. Delayed luteolysis during the first estrous cycle postpartum, persistent corpus luteum type I (PCL I), was defined as milk $\mathrm{P} 4$ concentrations $\geq 3 \mathrm{ng} / \mathrm{mL}$ for $\geq 19 \mathrm{~d}$ during the first postpartum estrous cycle. Delayed luteolysis during subsequent estrous cycles before AI, persistent corpus luteum type II (PCL II), was defined as milk $\mathrm{P} 4$ concentrations $\geq 3 \mathrm{ng} / \mathrm{mL}$ for $\geq 19$ d during subsequent postpartum estrous cycles.

Characteristics of the estrous cycle outlined above were determined before the first postpartum AI. In to- tal, results were available from $306,371,223,250$, and 146 cows for IOV1, DOV I, DOV II, PCL I, and PCL II, respectively.

\section{FA Analysis}

Milk samples were collected from 15 cows on each treatment at 30 and 60 DIM, and the samples were analyzed for milk FA composition. The samples were analyzed by GLC according to the method developed by Collomb et al. (2000) following extraction and methylation according to International Organization for Standardization (ISO) standards 14156:2001 (ISO, 2001) and 15884:2002 (ISO, 2002). Samples of the feed offered were collected at these time points and FA content was determined by GLC as described by Childs et al. (2008) following lipid extraction using a chloroform, methanol, and water mixture (Folch et al., 1957), and methylation using $\mathrm{NaOCH}_{3}$, methanol, and $\mathrm{BF}_{3}$ (Park and Goins, 1994). The FA compositions of the feeds offered is in Table 2.

\section{Breeding and Reproductive Performance}

Breeding commenced on April 8, 2009, and continued for 16 wk. Artificial insemination was carried out by a single experienced technician, and took place after morning and evening milkings. Cows were artificially inseminated $12 \mathrm{~h}$ after first showing signs of estrus. Tail paint and MooMonitor activity collars (Dairymaster) were used to aid heat detection. Body condition score was assessed (Edmonson et al., 1989) on 4 fixed calendar dates during the breeding season. The BCS assessment commenced on April 5, 2009 and took place on fixed calendar dates at intervals of approximately 4 wk thereafter. As a result, some of the LE-CLA cows were still receiving the LE-CLA supplement for the first 2 BCS assessment dates, whereas others had finished the LE-CLA supplementation period before the first BCS assessment date of April 5, 2009. Transrectal ultrasonography was carried out at 30 to $36 \mathrm{~d}$ and 60 to $66 \mathrm{~d}$ post-AI using a $5.0-\mathrm{MHz}$ transrectal transducer (Aloka SSD-500; Aloka Ltd., Tokyo, Japan) to diagnose pregnancy. Visualization of a fluid-filled horn and a viable embryo were used for positive identification of pregnancy. Three-week submission rate was defined as the proportion of cows inseminated within the first 3 wk of the breeding season. Six-week in-calf rate was defined as the proportion of cows pregnant within the first $6 \mathrm{wk}$ of the breeding season. Overall pregnancy rate was defined as the proportion of cows pregnant at the final herd scan on December 2, 2009. Cows that underwent embryo loss were defined as cows that were 
Table 2. Fatty acid composition ( $\mathrm{g} / 100 \mathrm{~g}$ of total FA) of the feeds offered to dairy cows on pasture

\begin{tabular}{|c|c|c|c|c|}
\hline FA & Grass & $\mathrm{PMR}^{1}$ & Concentrate & LE-CLA $^{2}$ \\
\hline $12: 0$ & 1.87 & 1.16 & 0.57 & 0.34 \\
\hline $12: 1$ & 1.71 & 1.52 & 0.03 & - \\
\hline $13: 0$ & 1.09 & 1.08 & - & 0.34 \\
\hline $13: 1$ cis -12 & 1.28 & 0.68 & - & - \\
\hline $14: 0$ & 1.54 & 3.88 & 0.93 & 1.11 \\
\hline trans 14:1 & - & 0.12 & - & - \\
\hline $15: 0$ & - & - & 0.42 & 0.13 \\
\hline $15: 1$ trans -10 & 2.33 & 1.79 & 0.16 & - \\
\hline $15: 1$ cis -10 & 3.86 & 2.69 & - & - \\
\hline $16: 0$ & 20.32 & 26.68 & 32.29 & 13.96 \\
\hline cis $16: 1$ & 2.31 & 1.16 & 0.63 & 0.07 \\
\hline trans $16: 1$ & - & 1.06 & - & - \\
\hline $17: 0$ & - & 0.23 & 0.17 & 0.21 \\
\hline $17: 1$ cis -10 & - & 0.29 & - & 0.04 \\
\hline $18: 0$ & 1.03 & 2.24 & 1.70 & 33.28 \\
\hline $18: 1$ cis -9 & 1.62 & 5.51 & 13.23 & 12.07 \\
\hline 18:1 trans -9 & - & 0.52 & 1.50 & 0.23 \\
\hline $18: 2$ cis -9, cis -12 & 5.58 & 15.15 & 36.32 & 1.01 \\
\hline 18:2 cis-9,trans-11 CLA $^{3}$ & - & - & - & 12.42 \\
\hline 18:2 trans-10,cis-12 CLA & - & - & - & 13.72 \\
\hline All trans $18: 2$ & 0.57 & 0.80 & 0.17 & 2.60 \\
\hline $18: 3$ cis- 6, cis -9, cis -12 & - & 0.11 & - & - \\
\hline $18: 3$ cis -9, cis -12, cis -15 & 41.76 & 18.05 & 3.20 & 0.02 \\
\hline 20:0 & 0.07 & 0.44 & 0.44 & 1.10 \\
\hline $20: 1$ cis -11 & - & - & 0.45 & 0.09 \\
\hline $20: 2$ cis- 11, cis- 14 & - & - & - & 0.03 \\
\hline $22: 0$ & 1.10 & 2.01 & 0.74 & 2.69 \\
\hline $22: 1$ & 1.85 & 0.69 & 0.16 & - \\
\hline $22: 4$ & 1.41 & 2.74 & 1.44 & 1.23 \\
\hline Total & 91.36 & 90.60 & 94.53 & 96.69 \\
\hline
\end{tabular}

${ }^{1}$ Partial mixed ration.

${ }^{2}$ Lipid-encapsulated conjugated linoleic acid.

${ }^{3} \mathrm{CLA}=$ conjugated linoleic acid.

diagnosed as pregnant at 30 to $36 \mathrm{~d}$ post-AI, but were then diagnosed as nonpregnant at 60 to $66 \mathrm{~d}$ post-AI.

\section{Statistical Analysis}

All statistical analysis was carried out using SAS (SAS System Inc., Cary, NC). Milk production, milk composition, and BCS data were analyzed using the MIXED procedure of SAS with repeated measures, using the Satterthwaite adjustment to calculate denominator degrees of freedom. The appropriate covariance structure for each repeated measures analysis was identified based on the Akaike Information Criterion model fit statistic. A first-order autoregressive covariance structure was selected. Treatment, treatment week, and their interaction were included as fixed effects, and block was included as a random effect. Parity and calving day of year were included as adjustment variables in all repeated measures models; if nonsignificant, these variables were removed and the models were rerun. Data for IOV1, the interval from calving to first AI, and interval from calving to conception were evaluated by the LIFETEST procedure of SAS using Kaplan-
Meier analysis to investigate the effect of treatment on the number of days from calving to commencement of luteal activity, first AI, and conception. The IOV1 was right-censored at $60 \mathrm{~d}$, calving-to-service interval was right-censored at the last date of AI use (June 15), and calving to conception interval was right-censored at the last date of the breeding period (September 25). All of the binary reproductive performance variables were analyzed using the FREQ procedure of SAS with the chi-squared test.

\section{RESULTS}

\section{Milk Production and BCS}

The milk production results are summarized in Table 3 and Figure 1. Milk fat concentration was reduced by LE-CLA treatment $(P<0.001)$, but the treatment-bytime interaction effect was not significant. During the supplementation period, milk fat yield decreased $(P=$ $0.03)$ by up to $8 \%$, milk yield increased $(P=0.003)$, and milk protein concentration decreased $(P<0.001)$. Milk solids yield (fat plus protein) was not affected. Milk fat 
Table 3. Milk production and composition of cows on lipid-encapsulated conjugated linoleic acid (LE-CLA) and control treatments (Trt)

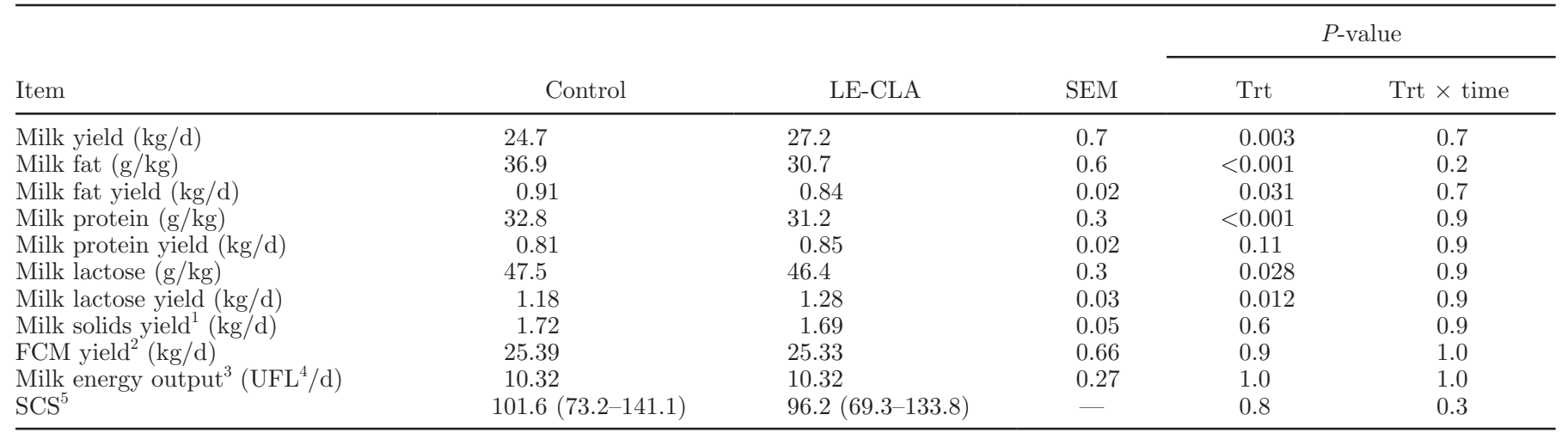

${ }^{1}$ Milk solids yield $=$ milk fat yield $(\mathrm{kg} / \mathrm{d})+$ milk protein yield $(\mathrm{kg} / \mathrm{d})$.

${ }^{2} 3.5 \%$ FCM yield $=0.4318 \times$ milk yield $(\mathrm{kg} / \mathrm{d})+16.23 \times$ milk fat yield $(\mathrm{kg} / \mathrm{d})$.

${ }^{3}$ Milk energy output $=0.054 \times$ fat concentration $(\%)+0.031 \times$ protein concentration $(\%)+0.028 \times$ lactose concentration $(\%)-0.015$.

${ }^{4} \mathrm{UFL}=$ unité fourragère lait; unit of net energy, equivalent to $1 \mathrm{~kg}$ of standard air-dried barley.

${ }^{5} \mathrm{SCS}$ is calculated by taking the natural logarithm of SCC values. Values are back-transformed least squares means, followed by $95 \%$ confidence limits in parentheses.

concentration and yield in LE-CLA-supplemented cows began to return toward levels similar to control cows after the end of the supplementation period (Figure 1). Supplementing cows with LE-CLA tended to increase BCS $(P=0.09$; Figure 2$)$.

\section{Estrous Cycle Characteristics}

Estrous cycle characteristics and IOV1 results are presented in Table 4. No effect was observed of LECLA supplementation on IOV1 (40.2 \pm 1.05 d vs. 40.3 $\pm 1.19 \mathrm{~d}$, control and LE-CLA, respectively, log rank probability of chi-squared test $=0.87$ ). The proportion of cows that continued to be anestrous at 60 DIM was 0.23 and 0.25 for control and CLA cows, respectively. Incidence of DOV I (35.1 vs. $36.1 \%$ ) and DOV II (16.7 vs. $14.6 \%$ ) were not affected by LE-CLA supplementation (both $P>0.6$ ). The LE-CLA supplementation had no effect on the incidence of PCL I (8.9 vs. $10.3 \%$ ) or PCL II (8.9 vs. $7.5 \%$, both $P>0.6)$.

\section{Reproductive Performance}

Reproductive performance data are summarized in Table 5. No effect was observed of LE-CLA supplementation on the interval from calving to first insemination $(71.8 \pm 1.84 \mathrm{~d}$ vs. $70.9 \pm 1.79 \mathrm{~d}$, control and LE-CLA, respectively, log rank probability of chi-squared test $=$ $0.5)$, or the interval from calving to conception (123.7 $\pm 4.68 \mathrm{~d}$ vs. $130.4 \pm 4.66 \mathrm{~d}$, control and LE-CLA, respectively, log rank probability of chi-squared test $=$ $0.2)$. No effect was observed of LE-CLA supplementation on conception rate to first (35.1 vs. 37.0; control and LE-CLA, respectively) or second service (38.5 vs.
$29.9 \%$, both $P>0.2$ ). In addition, no effect was found of CLA supplementation on $3 \mathrm{wk}$ submission rate (54.8 vs. $58.0 \%, P=0.5)$, embryo loss to first service $(15.2$ vs. $17.9 \%, P=0.7), 6$ week in-calf rate ( 43.6 vs. $37.0 \%$, $P=0.2)$, or overall pregnancy rate $(80.7$ vs. $76.0 \%, P$ $=0.3$.

\section{Milk FA Analysis}

Conjugated linoleic acid supplementation decreased (all $P<0.01$ ) the proportion of most short- and medium-chain FA in milk fat compared with control animals (Table 6), with the exception of C4:0, C14:0, and C15:0, which were not affected (all $P>0.3$ ). The proportion of C16:0 in milk fat was not affected by CLA supplementation $(P>0.1)$. The LE-CLA supplementation tended to increase $(P=0.07)$ the proportion of $\mathrm{C} 18: 0$ in milk fat, and increased the proportion of cis-9 C18:1 and cis-9,trans-11 CLA in milk fat (both $P<0.04$ ). No effect was observed of CLA supplementation on any other long-chain FA measured (all $P>0.08$ ). Overall, this resulted in a decrease in the proportion of de novo synthesized $(<\mathrm{C} 16: 0)$ FA $(P=0.03)$, and an increase in the proportion of preformed ( $>$ C17:0) FA in the milk fat of cows fed the LE-CLA supplement.

\section{DISCUSSION}

The feeding and management systems used in this study enabled accurate and reliable supplementation with LE-CLA to individual cows on a large-herd scale; it is the first time this has been achieved. We have demonstrated that LE-CLA supplementation during the first 60 DIM can be used as a management tool to 

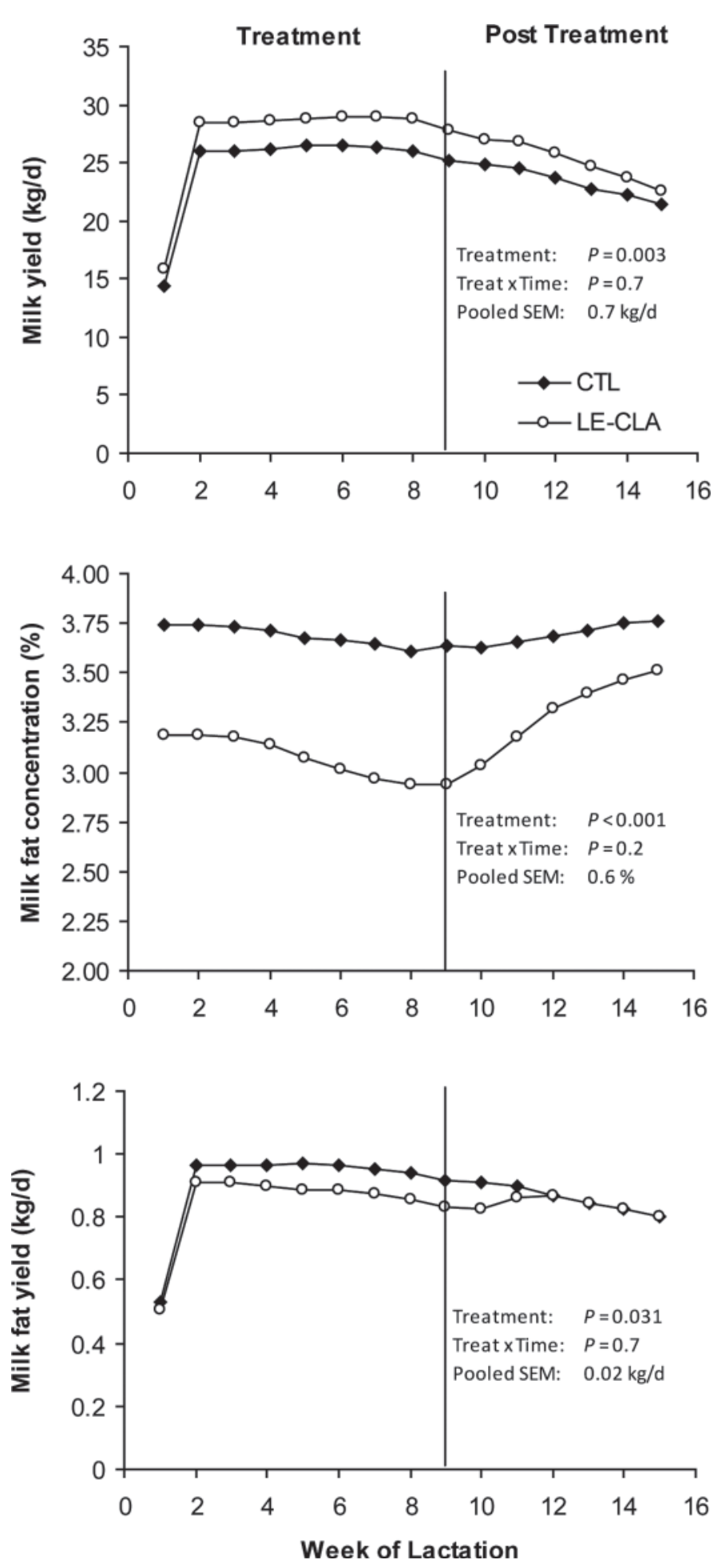

Figure 1. Temporal changes in milk yield, milk fat concentration, and milk fat yield during the treatment and post-treatment periods. The treatment period lasted from parturition to 60 DIM, and cows were fed either no supplement (CTL), or $51 \mathrm{~g} / \mathrm{d}$ of lipid-encapsulated conjugated linoleic acid (LE-CLA). The LE-CLA supplement provided $5 \mathrm{~g} / \mathrm{d}$ of both cis-9,trans-11 CLA and trans-10,cis-12 CLA. All values are least squares means. Treat $=$ treatment.

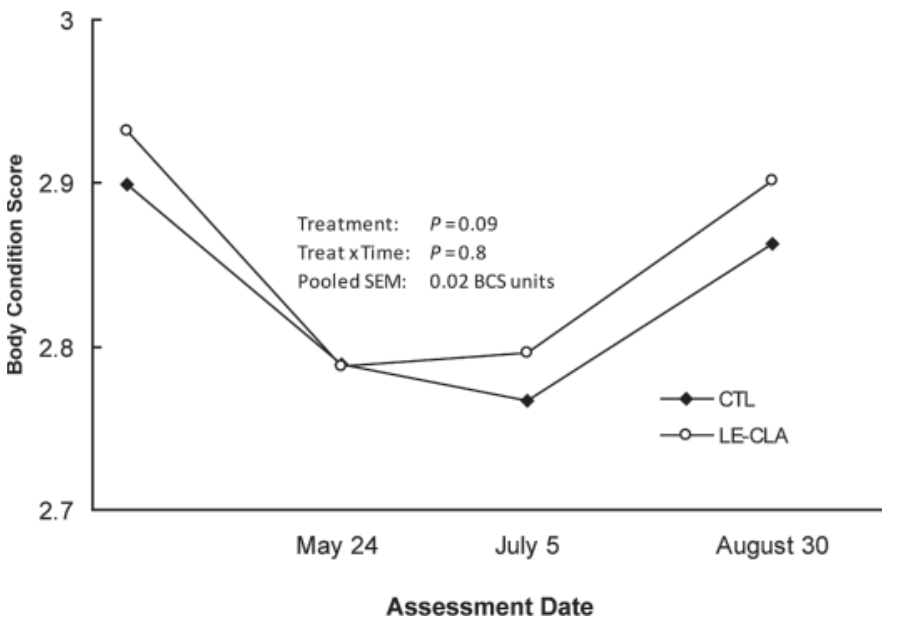

Figure 2. Effect of treatment on BCS. Body condition score was assessed on fixed calendar dates, just before the start of mating, followed by measurements approximately $6 \mathrm{wk}$ apart. The treatment period lasted from parturition to $60 \mathrm{DIM}$, and cows were fed either no supplement (CTL), or $51 \mathrm{~g} / \mathrm{d}$ of lipid-encapsulated conjugated linoleic acid (LE-CLA). The LE-CLA supplement provided $5 \mathrm{~g} / \mathrm{d}$ of both cis9,trans-11 CLA and trans-10,cis-12 CLA. All values are least squares means. Treat $=$ treatment.

temporarily reduce milk fat synthesis in pasture-based dairy cows. Despite observing a trend towards an improvement in BCS in cows supplemented with LE-CLA, the lack of an effect of LE-CLA on milk energy output suggests that most energy spared by reducing milk fat synthesis was partitioned towards increasing milk production. There was no effect of LE-CLA supplementation on any measure of reproductive performance or estrous cycle characteristics.

Fat is an economically important component of milk to dairy farmers. Extreme milk fat depression (MFD) may be undesirable, especially in regions where milk is primarily used for manufacturing purposes. Results from a previous study (Hutchinson et al., 2011) provided the justification for the level and duration of LE-CLA supplementation used in the present study to induce sufficient MFD to potentially improve energy status, but not markedly decrease income from milk.

The CLA dose fed in the present study $(5 \mathrm{~g} / \mathrm{d}$ of trans-10,cis-12 CLA) is similar to that fed by Hutchinson et al. (2011), although the supplement was fed in pelleted form, whereas in the current study, the granular supplement was fed directly to the cows, avoiding any potential degradation of the supplement during the pelleting process. In the current study, a decrease in milk fat concentration in LE-CLA cows occurred within a week after the initiation of treatment. No evidence exists of any adaptation to the treatment, as the data in Figure 1 show that maximal MFD occurred at wk 8 postpartum, at the end of the treatment period. 
Table 4. Estrous cycle characteristics of cows on lipid-encapsulated conjugated linoleic acid (LE-CLA) and control treatments

\begin{tabular}{lccc}
\hline Estrous cycle characteristic & Control & LE-CLA & $P$-value \\
\hline Interval to first ovulation $^{1}(\mathrm{~d})$ & $40.2( \pm 1.05)$ & $40.3( \pm 1.19)$ & 0.9 \\
Incidence of DOV I $^{2}(\%)$ & $35.1(67 / 191)$ & $36.1(65 / 180)$ & 0.8 \\
Incidence of DOV II $^{3}(\%)$ & $16.7(20 / 120)$ & $14.6(15 / 103)$ & 0.7 \\
Incidence of PCL I $^{4}(\%)$ & $8.9(11 / 124)$ & $10.3(13 / 126)$ & 0.7 \\
Incidence of PCL II $^{5}(\%)$ & $8.9(7 / 79)$ & $7.5(5 / 67)$ & 0.8 \\
\hline
\end{tabular}

${ }^{1}$ Interval to first ovulation data are mean values, followed by the standard error of the mean in parentheses. ${ }^{2} \mathrm{DOV} \mathrm{I}=$ delayed ovulation type $\mathrm{I}=$ milk $\mathrm{P} 4<3 \mathrm{ng} / \mathrm{mL}$ for $\geq 45 \mathrm{~d}$ postpartum, where $\mathrm{P} 4=$ progesterone.

${ }^{3} \mathrm{DOV}$ II $=$ delayed ovulation type II $=$ milk $\mathrm{P} 4<3 \mathrm{ng} / \mathrm{mL}$ for $\geq 12 \mathrm{~d}$ after the first occurrence of luteal activity. ${ }^{4} \mathrm{PCL} \mathrm{I}=$ persistent corpus luteum type $\mathrm{I}=$ milk $\mathrm{P} 4 \geq 3 \mathrm{ng} / \mathrm{mL}$ for $\geq 19 \mathrm{~d}$ during the first postpartum estrus cycle.

${ }^{5} \mathrm{PCL}$ II $=$ persistent corpus luteum type II = milk P4 $\geq 3 \mathrm{ng} / \mathrm{mL}$ for $\geq 19 \mathrm{~d}$ during subsequent postpartum estrous cycles.

The maximum depression in milk fat concentration was $18.8 \%$, greater than the $15.7 \%$ observed by (Hutchinson et al., 2011), who fed the same supplement but at a greater dose of $6.9 \mathrm{~g} / \mathrm{d}$ of trans-10,cis-12 LE-CLA. The greater decrease in milk fat concentration in the present study may suggest improved efficacy of the supplement, most likely attributable to avoiding any potential degradation during the pelleting process, as previously noted by Hutchinson et al. (2011).

The increase in milk yield in the current study supports the work of Bernal-Santos et al. (2003) and Mackle et al. (2003), but differs from the findings of Hutchinson et al. (2011), and Castañeda-Gutiérrez et al. (2005). Moore et al. (2004) hypothesized that during early lactation the extra energy afforded by a decrease in milk fat synthesis may be partitioned toward protein synthesis and milk production. We observed an increase in milk production and a decrease in milk protein concentration. Because of the increased milk yield, milk protein yield was not affected. There was also a decrease in milk lactose concentration with LE-CLA supplementation, but milk lactose yield was increased due to greater milk volume. To our knowledge, the current study is the first to report a decrease in milk lactose concentration with CLA supplementation. Overall, although milk constituent concentrations were decreased, the increase in milk synthesis negated these effects and resulted in no differences in milk solids yields.

In the current study, LE-CLA supplementation caused a decrease in the secretion of all FA, but those of de novo origin decreased to a greater extent. The LE-CLA decreased the proportion of de novo FA and increased the proportion of preformed FA in milk fat, results that support previous reports (Perfield et al., 2002; Moore et al., 2004; Kay et al., 2007). Trans10, cis-12 CLA decreases milk fat synthesis through coordinated decreases in expression of genes encoding key enzymes involved in the uptake and transport of

Table 5. Reproductive performance of cows on lipid-encapsulated conjugated linoleic acid (LE-CLA) and control treatments

\begin{tabular}{|c|c|c|c|}
\hline Item & Control & LE-CLA & $P$-value \\
\hline Calving-to-first-service interval $^{1}$ (d) & $71.8( \pm 1.79)$ & $70.9( \pm 1.84)$ & 0.5 \\
\hline Calving-to-conception interval $^{2}$ (d) & $123.7( \pm 4.68)$ & $130.4( \pm 4.66)$ & 0.2 \\
\hline 3 -wk submission $\operatorname{rate}^{3}(\%)$ & $54.8(103 / 188)$ & $58.0(105 / 181)$ & 0.5 \\
\hline Conception rate to first service $(\%)$ & $35.1(66 / 188)$ & $37.0(67 / 181)$ & 0.7 \\
\hline Conception rate to second service (\%) & $38.5(37 / 96)$ & $29.9(26 / 87)$ & 0.2 \\
\hline Embryo loss to first service $^{4}(\%)$ & $15.2(10 / 66)$ & $17.9(12 / 67)$ & 0.7 \\
\hline 6 -wk in-calf rate $(\%)$ & $43.6(82 / 188)$ & $37.0(67 / 181)$ & 0.2 \\
\hline Overall pregnancy rate $(\%)$ & $80.7(159 / 197)$ & $76.0(146 / 192)$ & 0.3 \\
\hline
\end{tabular}

${ }^{1}$ Calving-to-first-service interval data are mean values, followed by the standard error of the mean in parentheses.

${ }^{2}$ Calving-to-conception interval data are mean values, followed by the standard error of the mean in parentheses.

${ }^{3}$ Three-week submission rate $=$ proportion of cows inseminated in the first $3 \mathrm{wk}$ of the breeding season.

${ }^{4}$ Cows that underwent embryo loss were defined as cows that were scanned as pregnant at the 30 to $36 \mathrm{~d}$ postinsemination scan, but were then scanned as nonpregnant at the 60 to $66 \mathrm{~d}$ post-insemination scan.

${ }^{5}$ Six-week in-calf rate $=$ proportion of cows pregnant in the first 6 wk of the breeding season.

${ }^{6}$ Overall pregnancy rate $=$ proportion of cows pregnant at the final herd scan. 
Table 6. Milk FA composition ( $\mathrm{g} / 100 \mathrm{~g}$ of total FA) of cows on lipid-encapsulated conjugated linoleic acid (LE-CLA) and control treatments

\begin{tabular}{|c|c|c|c|c|}
\hline FA composition & Control & LE-CLA & SEM & $P$-value \\
\hline $4: 0$ & 2.71 & 2.67 & 0.073 & 0.74 \\
\hline $6: 0$ & 1.86 & 1.67 & 0.050 & 0.004 \\
\hline $8: 0$ & 1.22 & 1.04 & 0.043 & 0.001 \\
\hline 10:0 & 2.83 & 2.41 & 0.131 & 0.002 \\
\hline $10: 1$ & 0.27 & 0.22 & 0.020 & 0.008 \\
\hline $12: 0$ & 3.38 & 2.97 & 0.169 & 0.008 \\
\hline $12: 1 \mathrm{cis}$ and $13: 0$ & 0.31 & 0.27 & 0.014 & 0.009 \\
\hline 14:0 & 10.97 & 10.69 & 0.398 & 0.43 \\
\hline $15: 0$ & 1.60 & 1.52 & 0.038 & 0.129 \\
\hline $16: 0$ & 25.00 & 24.03 & 0.728 & 0.132 \\
\hline $16: 1$ cis -9 & 1.79 & 1.78 & 0.097 & 0.822 \\
\hline $17: 0$ & 1.15 & 1.11 & 0.022 & 0.114 \\
\hline 18:0 & 10.98 & 11.74 & 0.632 & 0.07 \\
\hline $18: 1$ cis- 9 & 21.58 & 23.18 & 0.739 & 0.032 \\
\hline Other $18: 1$ & 7.78 & 7.71 & 0.257 & 0.857 \\
\hline $18: 2$ cis- 9, cis- 12 & 1.28 & 1.35 & 0.079 & 0.312 \\
\hline Other $18: 2$ & 1.47 & 1.56 & 0.073 & 0.409 \\
\hline 18:2 cis-9,trans-11 CLA & 1.59 & 1.92 & 0.104 & 0.023 \\
\hline $18: 3$ cis -9, cis- 12, cis -15 & 0.67 & 0.75 & 0.050 & 0.116 \\
\hline 20:0 & 0.10 & 0.11 & 0.007 & 0.085 \\
\hline $20: 5 \mathrm{EPA}^{1}$ & 0.09 & 0.09 & 0.005 & 0.947 \\
\hline $22: 0$ & 0.17 & 0.10 & 0.053 & 0.363 \\
\hline $22: 5 \mathrm{DPA}^{2}$ & 0.11 & 0.11 & 0.008 & 0.452 \\
\hline \multicolumn{5}{|l|}{ FA origin } \\
\hline De novo ${ }^{3}$ & 25.17 & 23.48 & 0.820 & 0.03 \\
\hline $16: 0$ and $16: 1$ & 26.81 & 25.81 & 0.796 & 0.145 \\
\hline Preformed $^{4}$ & 47.13 & 49.88 & 1.514 & 0.026 \\
\hline
\end{tabular}

${ }^{1} \mathrm{EPA}=$ eicosapentaenoic acid.

${ }^{2} \mathrm{DPA}=$ docosahexaenoic acid.

${ }^{3}$ Milk FA synthesized in the mammary gland of chain length $\mathrm{C} 4$ to $\mathrm{C} 15$.

${ }^{4}$ Milk FA derived from the uptake of circulating fatty acids, of chain length greater than C16.

preformed FA, in addition to enzymes involved in the desaturation of FA, formation of triglycerides, and de novo FA synthesis (Baumgard et al., 2002).

Although the milk fat-depressing effects of CLA are generally accepted, the subsequent effect on energy status is more equivocal. Some studies reported improvements in energy status with CLA supplementation (Odens et al., 2007; Hutchinson et al., 2011); however, absence of an effect of CLA on energy status has been reported (Bernal-Santos et al., 2003; CastañedaGutiérrez et al., 2005). In studies where CLA did not improve energy status, it was generally hypothesized that any energy saved from the decrease in milk fat synthesis was partitioned toward greater milk production, such that milk energy output remained unchanged (Bernal-Santos et al., 2003). The present study differs from previous reports in that milk energy output was unaffected by LE-CLA supplementation, but a trend toward improved BCS in LE-CLA-treated cows was observed. Due to the on-farm nature of the current study, it was not possible to measure DMI. In previous studies where DMI has been measured, CLA had no effect on DMI in cows consuming a TMR (Bernal-Santos et al.,
2003; Moore et al., 2004) or pasture (Kay et al., 2006, 2007) diet.

Mackle et al. (2003) suggested that energy spared from a decrease in milk fat synthesis likely has a greater positive effect on milk production in pasturefed cows than cows fed a TMR diet that could more closely meet energy requirements. The current study, along with data from Kay et al. (2006), Mackle et al. (2003), and Medeiros et al. (2010) support this hypothesis. The work of Kay et al. (2007) is the only study of cows receiving a pasture diet where CLA-induced MFD resulted in decreased milk energy output, but was not accompanied by an increase in milk yield. In that study, much greater levels of MFD were achieved $(>40 \%)$ due to abomasal infusion of the CLA, which avoided rumen biohydrogenation of the supplement. Positive milk yield responses were not observed at more severe (>35\%) levels of MFD (Kay et al., 2006). It is reasonable to conclude that in pasture-based systems of dairy production, where milk production is limited by energy intake, the extra energy spared by CLA-induced MFD is partitioned primarily toward milk production rather than body reserves. It seems likely that overall 
energy status is only improved in situations where the cow is already producing at full potential.

No effect of LE-CLA was observed on any of the reproduction variables or estrous cycle characteristics measured. No previous work in which dairy cows were supplemented with CLA investigated the effects on estrous cycle characteristics. The overall incidence of both DOV I (35.1\%) and DOV II (15.7\%) in the current study is greater than those observed by Opsomer et al. (1998; 20.5 and $3 \%$, respectively) and Royal et al. (2000; 12.9 and $10.6 \%$, respectively). The high incidence of delayed ovulation observed in the present study is indicative of a widespread fertility problem in the herd, as cows with extended postpartum anestrus intervals had lower submission, conception, and pregnancy rates than cycling animals (McDougall et al., 2001). This is reflected in the suboptimal fertility performance of the herd, with conception rates to first service in the current study (35.1 to $37.0 \%$ ) less than reported in pasture-based systems (Buckley et al., 2003: 49\%; Horan et al., 2004: 47 to 56\%). Similarly, the embryo loss rates of 15.2 to $17.9 \%$ were greater than those reported by Silke et al. (2002; 6.1 to 7.2\%) and Horan et al. (2004; 7.5\%), from comparable studies in Irish pasture-based dairy herds. Figures of 54 to $58 \%$ for 3 -wk submission rate and 37 to $44 \%$ for 6 -wk in-calf rate in the current study are less than the target rates for seasonal-calving pasture based systems of $>80 \%$ for 3 -wk submission rate and $>68 \%$ for 6 -wk in-calf rate (McDougall, 2006).

\section{CONCLUSIONS}

Supplementation with LE-CLA-induced MFD in early-lactation, pasture-fed dairy cows. Due to increased milk yield in LE-CLA-supplemented cows, no effect on milk energy output occurred. No effect of LE-CLA supplementation was observed on any estrous cycle characteristic or measure of reproductive performance. In grass-based systems of dairy production, where milk production is limited by energy intake, any energy spared by a decrease in milk fat synthesis is partitioned toward increased milk production rather than improving the energy status and subsequent reproductive performance of the cow.

\section{ACKNOWLEDGMENTS}

The authors thank J. Crimmins (Curraghdermot Farm, Castlelyons, Ireland), P. Crimmins (Curraghdermot Farm), and the Curraghdermot Farm staff for management and care of the animals. The technical assistance of B. Curtin and J. Kenneally (Teagasc, Moorepark, Ireland) is appreciated. Funding from the
National Development Plan and provision of the LECLA product by BASF (Ludwigshafen, Germany) are gratefully acknowledged.

\section{REFERENCES}

Bauman, D. E., and W. B. Currie. 1980. Partitioning of nutrients during pregnancy and lactation: A review of mechanisms involving homeostasis and homeorhesis. J. Dairy Sci. 63:1514-1529.

Baumgard, L. H., E. Matitashvili, B. A. Corl, D. A. Dwyer, and D. E. Bauman. 2002. Trans-10, cis-12 conjugated linoleic acid decreases lipogenic rates and expression of genes involved in milk lipid synthesis in dairy cows. J. Dairy Sci. 85:2155-2163.

Beam, S. W., and W. R. Butler. 1999. Effects of energy balance on follicular development and first ovulation in postpartum dairy cows. J. Reprod. Fertil. Suppl. 54:411-424.

Bernal-Santos, G., J. W. Perfield II, D. M. Barbano, D. E. Bauman, and T. R. Overton. 2003. Production responses of dairy cows to dietary supplementation with conjugated linoleic acid (CLA) during the transition period and early lactation. J. Dairy Sci. 86:3218-3228.

Buckley, F., K. O'Sullivan, J. F. Mee, R. D. Evans, and P. Dillon. 2003. Relationships among milk yield, body condition, cow weight, and reproduction in spring-calved Holstein-Friesians. J. Dairy Sci. $86: 2308-2319$

Castañeda-Gutiérrez, E., B. C. Benefield, M. J. de Veth, N. R. Santos, R. O. Gilbert, W. R. Butler, and D. E. Bauman. 2007. Evaluation of the mechanism of action of conjugated linoleic acid isomers on reproduction in dairy cows. J. Dairy Sci. 90:4253-4264.

Castañeda-Gutiérrez, E., T. R. Overton, W. R. Butler, and D. E. Bauman. 2005. Dietary supplements of two doses of calcium salts of conjugated linoleic acid during the transition period and early lactation. J. Dairy Sci. 88:1078-1089.

Childs, S., C. O. Lynch, A. A. Hennessy, C. Stanton, D. C. Wathes, J. M. Sreenan, M. G. Diskin, and D. A. Kenny. 2008. Effect of dietary enrichment with either n-3 or n- 6 fatty acids on systemic metabolite and hormone concentration and ovarian function in heifers. Animal 2:883-893.

Collomb, M., and T. Buhler. 2000. Analyse de la composition en acides gras de la graisse de lait. I. Optimisation et validation d'une méthode générale à haute résolution. Mitt. Lebensm. Hyg. 91:306332.

Darwash, A. O., G. E. Lamming, and J. A. Woolliams. 1997. Estimation of genetic variation in the interval from calving to postpartum ovulation of dairy cows. J. Dairy Sci. 80:1227-1234.

de Veth, M. J., D. E. Bauman, W. Koch, G. E. Mann, A. M. Pfeiffer, and W. R. Butler. 2009. Efficacy of conjugated linoleic acid for improving reproduction: A multi-study analysis in early-lactation dairy cows. J. Dairy Sci. 92:2662-2669.

de Veth, M. J., J. M. Griinari, A. M. Pfeiffer, and D. E. Bauman. 2004. Effect of CLA on milk fat synthesis in dairy cows: Comparison of inhibition by methyl esters and free fatty acids, and relationships among studies. Lipids 39:365-372.

Diskin, M. G., D. R. Mackey, J. F. Roche, and J. M. Sreenan. 2003. Effects of nutrition and metabolic status on circulating hormones and ovarian follicle development in cattle. Anim. Reprod. Sci. 78:345-370.

Edmonson, A. J., I. J. Lean, L. D. Weaver, T. Farver, and G. Webster. 1989. A body condition scoring chart for Holstein dairy cows. J. Dairy Sci. 72:68-78.

Folch, J., M. Lees, and G. H. S. Stanley. 1957. A simple method for the isolation and purification of total lipides from animal tissues. J. Biol. Chem. 226:497-509.

Horan, B., J. F. Mee, M. Rath, P. O'Connor, and P. Dillon. 2004 The effect of strain of Holstein-Friesian cow and feeding system on reproductive performance in seasonal-calving milk production systems. Anim. Sci. 79:453-467.

Hutchinson, I., M. J. de Veth, C. Stanton, R. J. Dewhurst, P. Lonergan, A. C. O. Evans, and S. T. Butler. 2011. Effects of lipidencapsulated conjugated linoleic acid supplementation on milk 
production, bioenergetic status and indicators of reproductive performance in lactating dairy cows. J. Dairy Res. 78:308-317.

ISO (International Organization for Standardization). 2001. Milk and milk products - Extraction methods for lipids and liposoluble compounds. ISO, Geneva, Switzerland.

ISO (International Organization for Standardization). 2002. Milk fatPreparation of fatty acid methyl esters. ISO, Geneva Switzerland.

Kay, J. K., T. R. Mackle, D. E. Bauman, N. A. Thomson, and L. H. Baumgard. 2007. Effects of a supplement containing trans-10, cis12 conjugated linoleic acid on bioenergetic and milk production parameters in grazing dairy cows offered ad libitum or restricted pasture. J. Dairy Sci. 90:721-730.

Kay, J. K., J. R. Roche, C. E. Moore, and L. H. Baumgard. 2006. Effects of dietary conjugated linoleic acid on production and metabolic parameters in transition dairy cows grazing fresh pasture. J. Dairy Res. 73:367-377.

Leroy, J., A. Van Soom, G. Opsomer, and P. E. J. Bols. 2008. The consequences of metabolic changes in high-yielding dairy cows on oocyte and embryo quality. Animal 2:1120-1127.

Mackle, T. R., J. K. Kay, M. J. Auldist, A. K. H. McGibbon, B. A. Philpott, L. H. Baumgard, and D. E. Bauman. 2003. Effects of abomasal infusion of conjugated linoleic acid on milk fat concentration and yield from pasture-fed dairy cows. J. Dairy Sci. 86:644-652.

McDougall, S. 2006. Reproduction performance and management of dairy cattle. J. Reprod. Dev. 52:185-194.

McDougall, S., A. A. Cullum, F. M. Anniss, and F. M. Rhodes. 2001. Treatment of anovulatory anoestrous postpartum dairy cows with a gonadotropin-releasing hormone $(\mathrm{GnRH})$, prostaglandin $\mathrm{F}-2$ alpha, GnRH regimen or with progesterone and oestradiol benzoate. N. Z. Vet. J. 49:168-172.

Medeiros, S. R., D. E. Oliveira, L. J. M. Aroeira, M. A. McGuire, D. E. Bauman, and D. P. D. Lanna. 2010. Effects of dietary supplementation of rumen-protected conjugated linoleic acid to grazing cows in early lactation. J. Dairy Sci. 93:1126-1137.

Moore, C. E., H. C. Hafliger, O. B. Mendivil, S. R. Sanders, D. E. Bauman, and L. H. Baumgard. 2004. Increasing amounts of conjugated linoleic acid (CLA) progressively reduces milk fat synthesis immediately postpartum. J. Dairy Sci. 87:1886-1895.
O'Mara, F. 1997. A Net Energy System for Cattle and Sheep. Department of Animal Science and Production, Faculty of Agriculture, University College Dublin, Belfield, Dublin, Ireland.

Odens, L. J., R. Burgos, M. Innocenti, M. J. VanBaale, and L. H. Baumgard. 2007. Effects of varying doses of supplemental conjugated linoleic acid on production and energetic variables during the transition period. J. Dairy Sci. 90:293-305.

Opsomer, G., M. Coryn, H. Deluyker, and A. de Kruif. 1998. An analysis of ovarian dysfunction in high yielding dairy cows after calving based on progesterone profiles. Reprod. Domest. Anim. 33:193-204.

Park, P. W., and R. E. Goins. 1994. In situ preparation of fatty acid methyl esters for analysis of fatty acid composition in foods. J. Food Sci. 59:1262-1266.

Perfield, J. W. II, G. Bernal-Santos, T. R. Overton, and D. E. Bauman. 2002. Effects of dietary supplementation of rumen-protected conjugated linoleic acid in dairy cows during established lactation. J. Dairy Sci. 85:2609-2617.

Royal, M. D., A. O. Darwash, A. P. E. Flint, R. Webb, J. A. Woolliams, and G. E. Lamming. 2000. Declining fertility in dairy cattle: Changes in traditional and endocrine parameters of fertility. Anim. Sci. 70:487-501.

Santos, J. E. P., T. R. Bilby, W. W. Thatcher, C. R. Staples, and F. T. Silvestre. 2008. Long chain fatty acids of diet as factors influencing reproduction in cattle. Reprod. Domest. Anim. 43:23-30.

Sauer, M. J., J. A. Foulkes, A. Worsfold, and B. A. Morris. 1986. Use of progesterone 11-glucuronide-alkaline phosphatase conjugate in a sensitive microtitre-plate enzymeimmunoassay of progesterone in milk and its application to pregnancy testing in dairy cattle. J. Reprod. Fertil. 76:375-391.

Silke, V., M. G. Diskin, D. A. Kenny, M. P. Boland, P. Dillon, J. F. Mee, and J. M. Sreenan. 2002. Extent, pattern and factors associated with late embryonic loss in dairy cows. Anim. Reprod. Sci. $71: 1-12$.

Staples, C. R., J. M. Burke, and W. W. Thatcher. 1998. Influence of supplemental fats on reproductive tissues and performance of lactating cows. J. Dairy Sci. 81:856-871. 